\title{
Multi Criteria Analysis of Built-Up Land Suitability in Sleman Regency, Special Region of Yogyakarta Province
}

\author{
Nabila Dety Novia Utami ${ }^{1}$, Supriatna Supriatna ${ }^{2, *}$, and Hayuning Anggrahita ${ }^{3}$ \\ 1,2,3 Department of Geography, Faculty of Mathematics and Natural Sciences, Depok - Universitas Indonesia
}

\begin{abstract}
The existence of Mount Merapi in Sleman Regency makes the agricultural land so fertile and that becomes the attraction for humans to occupy the region. A high population growth will lead to the people demand of the availability built-up land higher. However, the volcanic activity of Mount Merapi becomes a threat to the people who live in the area of Disaster Prone Areas of Mount Merapi. This study presented an application of multi criteria analysis technique as an approach to deal with the built-up land suitability. Physical and accessibility data such as slope, landform, distance from the river, distance from road, distance from the center of economic activities, and Mount Merapi disasterprone area will be used as limiting factor of built-up land. The result shows that the majority of Sleman Regency is suitable for built-up land.
\end{abstract}

Keywords: Built-Up Land; Land Suitability; and Multi Criteria Analiysis (MCA).

\section{Introduction}

One of the regencies in Indonesia with high percentage of population growth is Sleman Regency. According to Baskoro [1], during the years 1995 - 2005 population growth in Sleman Regency reached 2.7\% which is much higher than the national population growth. The rapid growth of the population raises many new problems on the land. This population growth will cause the need for land as a space for their activities to increase and will lead to a kind of competition to get a suitable space in accordance with various interests and human needs. According Arini [2], the increase in the number of population affect the process of development and development activities of a region and the increasing need for space or land.

Basically, the population has a basic need for land to be used as settlements or other buildings to conduct socioeconomic activities. The higher the population will cause the need for land to be built higher so that land conversion occurs. Physical condition and accessibility condition are the factors that need to be considered in choosing the built-up land in the research area. Physical factors are elevation, slope, landform, and distance from rivers, meanwhile accessibility factors are distance from roads, and distance from the center of economic activities. The existence of disaster prone areas will be another factor in the selection of areas to be settled, which of course settlements should not be built on the area or the existence of settlements built minimized in the area to avoid high risk against disaster. Based on this, it is necessary to analyze the land suitability area in Sleman Regency. Monitoring built-up land suitability, and land use changes will be a good step to develop low carbon society.

\section{Methods}

Data processing and analysis using ArcGIS 10.3 software. The variable in spatial analysis is built-up land development variable and built-up land suitability variable that consist of variables such as elevation, slope, landform, distance from the river network, distance from road network, distance from the center of economic growth elevation, and Mount Merapi disaster-prone area. The GIS analysis used overlay analysis [3] with its result such as suitable area, less suitable area, and not suitable area for built-up land.

The population's tendency in developing the built-up land is based on regulations on land use as a built-up land. As outlined in the SNI 03-1733 of 2004 on the Procedure of Built-Up Land Environment Planning [4], that the appropriate slopes for the built-up land are 0 $8 \%$, the rest, $9-15 \%$ and more than $15 \%$ required technical engineering. According to RI Government Regulation no. 38/2011 about the river, the area that suitable for the built-up land is located more than 100 meters, the closer to the river the lower the suitability as

* Corresponding author: ysupris@gmail.com 
it will disrupt the river environment. In addition, in the journal Planning for Urban Region and Environment Volume 3 No. 1 January 2014 [4], the suitable area for built-up land are closer to the roads and economic centers, so that the accessibility is easy and the economic needs of the population are met optimally.

\section{Result and Discussions}

\subsection{Slope}

Based on the Implementation Procedures of Built-Up Land Environment Planning, the slopes that have a high scoring to create built-up land are slope of $0 \%-8 \%$, because they do not require technical engineering on the land, then those with moderate scoring are slope of $9 \%$ $15 \%$ with the required technical engineering on the land, and the last is the slope with the lowest scoring is the slope with $>15 \%$ because of course requires further

\begin{tabular}{|c|c|c|}
\hline Slope & Area (Ha) & Percentage \\
\hline$<\mathbf{9 \%}$ & 52.296 & $91 \%$ \\
\hline $\mathbf{9 - 1 5 \%}$ & 3.157 & $5 \%$ \\
\hline$>\mathbf{1 5 \%}$ & 2.160 & $4 \%$ \\
\hline Total & 57.613 & $100 \%$ \\
\hline
\end{tabular}

technical engineering on the land.

In general, based on the table below, the study area is dominated by slopes of $<9 \%$ with, then in the second is slope of $9-15 \%$, and the latter is a slope of $>15 \%$.

Table 1. Area and Percentage of Slope Areas in Sleman Regency

Source: Data Processing, 2018

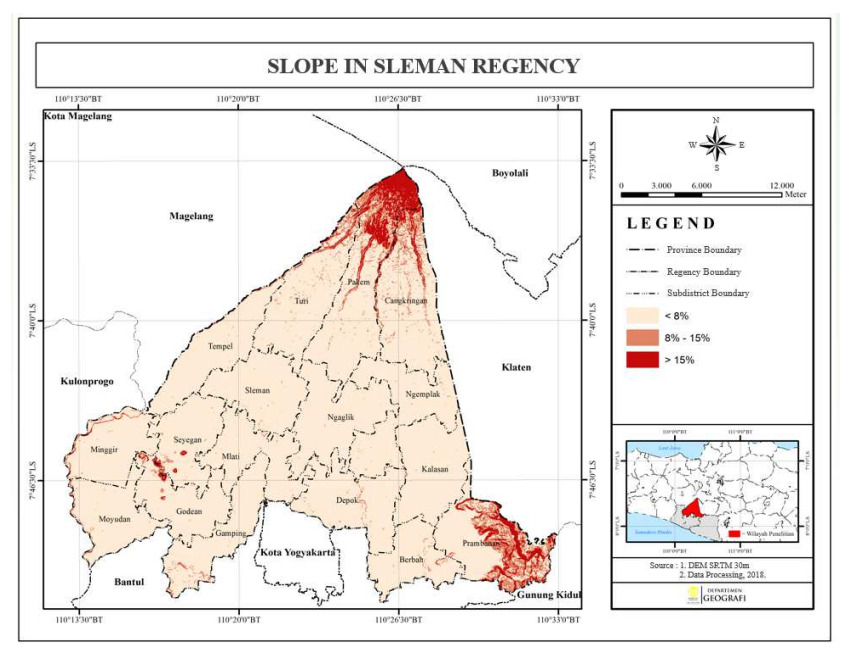

Fig. 3. Slope Map of Sleman Regency.

Source: Data Processing, 2018

\subsection{Landform}

Landform is the result of morphometry between elevation and slope variables. In the landform classification made by I Made Sandy [5], the landform based on high altitude, ranging from low region $(<500 \mathrm{~m}$ asl), middle region $(500-1000 \mathrm{~m}$ asl), and high region $(>1000 \mathrm{~m} \mathrm{asl})$. In the research area, consists of a landform from flat area to very steep mountainous area. The landform that has a high scoring for the built-up land area flat area and plateau area, because the slope class is less than $15 \%$ and its elevation are in the low and middle region. The lanform with the hilly area to the flat mountainous area has a medium scoring, and, moreover, the landform from the not sto steep mountainous area to the very steep mountainous area has a low scoring for the built-up land.

From Table 4, we can know that the Sleman Regency is dominated by flat landform with an area of 48,146 hectares or $83.57 \%$ of the researach area. As for the plateau landform has an area of 6.296 or $10.93 \%$ of the research area. The third largest area of the landform is not to steep mountainous landform with an area of 1.005 $\mathrm{Ha}$ or $1.74 \%$, followed by the steep mountainous landform with $972 \mathrm{Ha}$ or $1.69 \%$. Furthermore, the fifth largest landform is hilly landform with a percentage of $1.31 \%$, then the steep hill landform with $0.5 \%$, then the very steep mountainous landform with $0.22 \%$, followed by very steep hill landform with $0.03 \%$ and the last landform with the smallest area is flat mountainous area with an area of $6 \mathrm{Ha}$ or $0.01 \%$.

Table 4. Area and Percentage of Landform in Sleman Regency

\begin{tabular}{|l|c|c|}
\hline \multicolumn{1}{|c|}{ Landform Class } & Area (Ha) & Percentage \\
\hline Steep Hill & 289 & $0,50 \%$ \\
\hline Very Steep Hill & 14 & $0,03 \%$ \\
\hline Hilly & 756 & $1,31 \%$ \\
\hline $\begin{array}{l}\text { Not to Steep } \\
\text { Mountainous }\end{array}$ & 1.005 & $1,74 \%$ \\
\hline Steep Mountainous & 972 & $1,69 \%$ \\
\hline Flat Mountainous & 6 & $0,01 \%$ \\
\hline $\begin{array}{l}\text { Very Steep } \\
\text { Mountainous }\end{array}$ & 128 & $0,22 \%$ \\
\hline Plateau & 6.296 & $10,93 \%$ \\
\hline Flat & 48.146 & $83,57 \%$ \\
\hline Total & 57.613 & $100,00 \%$ \\
\hline
\end{tabular}

Source: Data Processing, 2018

There are 5 subdistricts in which the entire subdistrict is flad landform, namely Ngemplak, Ngaglik, Kalasan, Sleman, and Mlati. Meanwhile, other subdistricts have other types of landform. Prambanan subdistrict has the largest area of hilly landform, and becomes the only district that has hilly landform. Meanwhile, Cangkringan is dominated by the plateau landform with 2,496 Ha. Pakem became the subdistrict with the largest area of steep hill landform with 137.4 ha, flat mountanous landform with $3.6 \mathrm{Ha}$, not to steep mountainous with 580.2 ha, steep mountainous with 840.4 ha, and very steep mountainous landform with $125.3 \mathrm{Ha}$. 


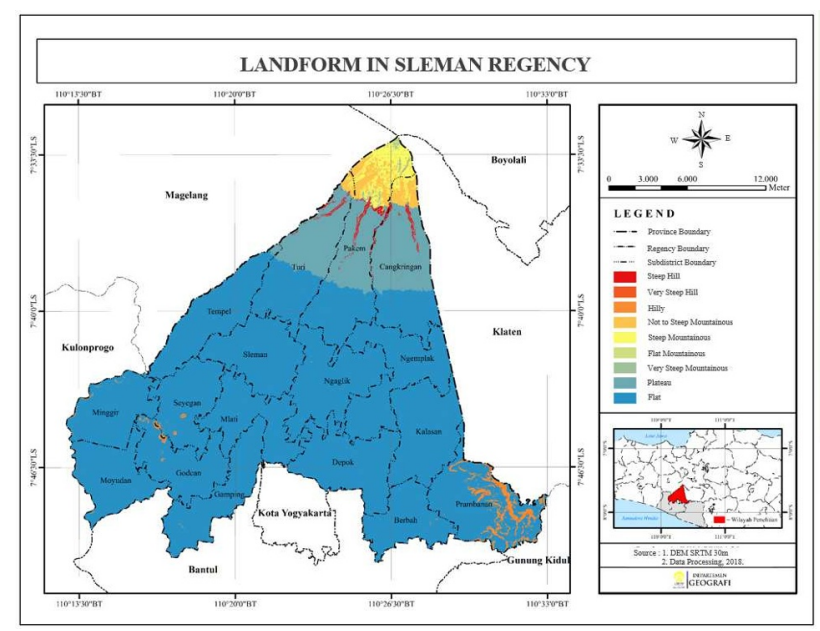

Fig. 4. Landform Map of Sleman Regency. Source: Data Processing, 2018

\subsection{Distance from River}

The distance from the river is based on government regulations on rivers having ideal border rules with a distance of 0 - 50 meters. The border with a distance of 0 - 50 meters in this study is seen as a region that has a scoring for the smallest built-up land suitability. Furthermore, for a border area of 50 to 100 meters distance is considered a medium scoring area. As for the area with a distance of more than 100 meters from the river is considered as the region that has the highest location scoring of built-up land suitability areas. This classification is done to keep the river function well and maintain the sustainability of the river itself.

Table 4. Percentange Area of Distance from River in Sleman Regency

\begin{tabular}{|l|c|c|c|}
\hline \multirow{2}{*}{ Subdistrict } & \multicolumn{3}{|c|}{ Distance from River } \\
\cline { 2 - 4 } & $<50 \mathrm{~m}$ & $51-100 \mathrm{~m}$ & $>100 \mathrm{~m}$ \\
\hline Berbah & $9,8 \%$ & $8,6 \%$ & $81,6 \%$ \\
\hline Cangkringan & $21,2 \%$ & $19,6 \%$ & $59,2 \%$ \\
\hline Depok & $12,1 \%$ & $11,2 \%$ & $76,8 \%$ \\
\hline Gamping & $11,5 \%$ & $10,5 \%$ & $78,0 \%$ \\
\hline Godean & $14,6 \%$ & $13,7 \%$ & $71,7 \%$ \\
\hline Kalasan & $18,8 \%$ & $17,2 \%$ & $64,1 \%$ \\
\hline Minggir & $18,6 \%$ & $15,1 \%$ & $66,3 \%$ \\
\hline Mlati & $16,8 \%$ & $15,0 \%$ & $68,2 \%$ \\
\hline Moyudan & $17,5 \%$ & $14,1 \%$ & $68,4 \%$ \\
\hline Ngaglik & $19,0 \%$ & $18,1 \%$ & $62,9 \%$ \\
\hline Ngemplak & $17,2 \%$ & $16,2 \%$ & $66,6 \%$ \\
\hline Pakem & $18,8 \%$ & $18,2 \%$ & $63,0 \%$ \\
\hline Prambanan & $15,8 \%$ & $13,7 \%$ & $70,6 \%$ \\
\hline Seyegan & $13,6 \%$ & $12,8 \%$ & $73,7 \%$ \\
\hline Sleman & $21,4 \%$ & $20,2 \%$ & $58,4 \%$ \\
\hline Tempel & $21,9 \%$ & $19,2 \%$ & $58,9 \%$ \\
\hline Turi & $19,4 \%$ & $18,5 \%$ & $62,1 \%$ \\
\hline
\end{tabular}

Source: Data Processing, 2018

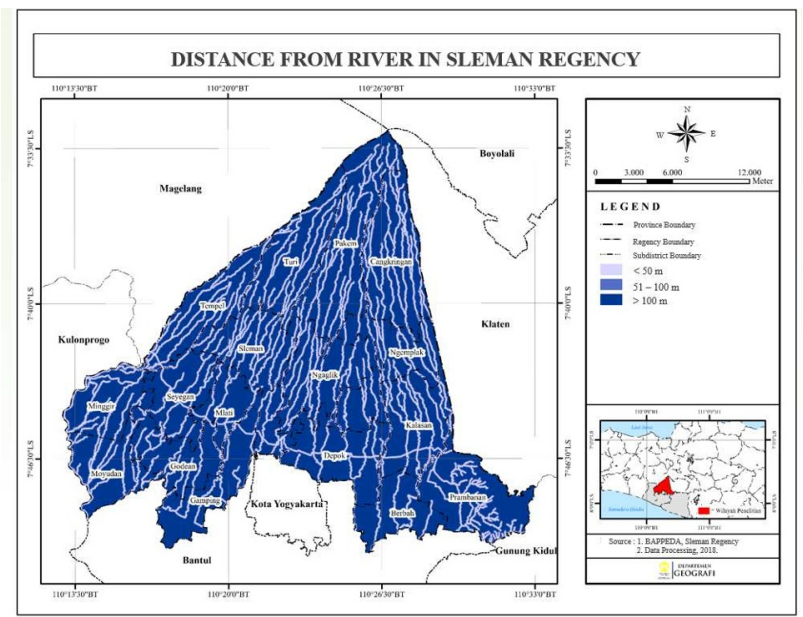

Fig. 4. Distance from River Map of Sleman Regency. Source: Data Processing, 2018

\subsection{Distance from Road}

Distance from the road based on the Journal Planning for Urban Region and Environment, is one of the important determinants for the built-up land suitability. The road will be use for transportation tool to make it easier for residents to mobilize people, goods, or services by tool of transportation in the form of the road. Based on the predetermined classification, that the further distance the land is built from the road, the more it has a small scoring for the suitability of the built-up land. Distance from 0-100 meters from the road has a high score for the suitability of the built-up land, then the distance of 100 750 meters is considered as an area that has a moderate score for the suitability of the built-up land, the last distance of more than 750 meters is considered as the area that has the lowest score for suitability of built-up land.

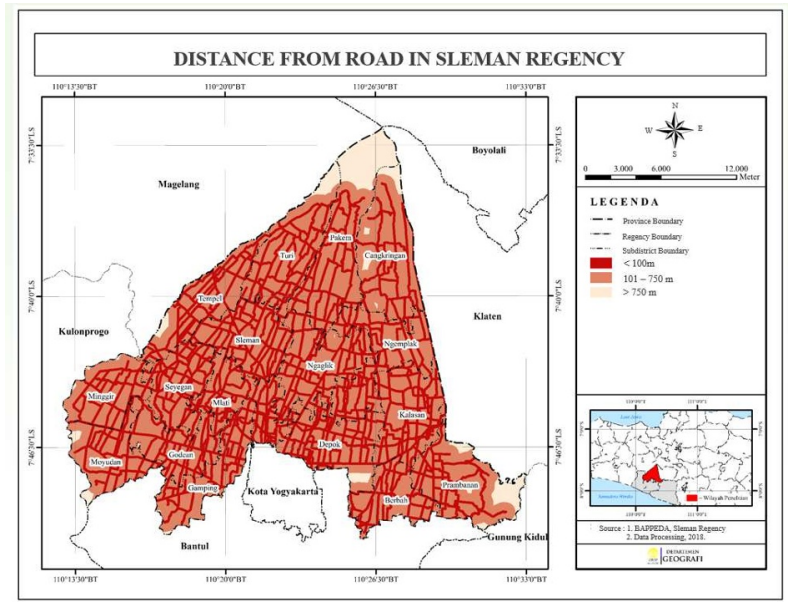

Fig. 5. Distance from Road Map of Sleman Regency. Source: Data Processing, 2018. 
Table 5. Percentange Area of Distance from Road in Sleman Regency

\begin{tabular}{|l|c|c|c|}
\hline \multirow{2}{*}{ Subdistrict } & \multicolumn{3}{|c|}{ Distance from Road } \\
\cline { 2 - 4 } & $<100 \mathrm{~m}$ & $101-750 \mathrm{~m}$ & $>750 \mathrm{~m}$ \\
\hline Berbah & $39,92 \%$ & $59,98 \%$ & $0,10 \%$ \\
\hline Cangkringan & $26,43 \%$ & $67,05 \%$ & $6,52 \%$ \\
\hline Depok & $41,35 \%$ & $55,06 \%$ & $3,59 \%$ \\
\hline Gamping & $37,52 \%$ & $61,83 \%$ & $0,65 \%$ \\
\hline Godean & $40,47 \%$ & $59,53 \%$ & $0,00 \%$ \\
\hline Kalasan & $42,01 \%$ & $57,99 \%$ & - \\
\hline Minggir & $30,92 \%$ & $67,66 \%$ & $1,43 \%$ \\
\hline Mlati & $47,82 \%$ & $52,18 \%$ & - \\
\hline Moyudan & $32,70 \%$ & $61,83 \%$ & $5,46 \%$ \\
\hline Ngaglik & $40,07 \%$ & $59,90 \%$ & $0,04 \%$ \\
\hline Ngemplak & $39,92 \%$ & $60,08 \%$ & - \\
\hline Pakem & $25,08 \%$ & $48,63 \%$ & $26,29 \%$ \\
\hline Prambanan & $25,84 \%$ & $58,89 \%$ & $15,27 \%$ \\
\hline Seyegan & $46,02 \%$ & $53,98 \%$ & - \\
\hline Sleman & $46,94 \%$ & $53,06 \%$ & - \\
\hline Tempel & $38,00 \%$ & $58,93 \%$ & $3,07 \%$ \\
\hline Turi & $33,97 \%$ & $58,39 \%$ & $7,64 \%$ \\
\hline \multicolumn{4}{|c|}{ Source: Data Processing, 2018 } \\
\hline
\end{tabular}

\subsection{Distance from Center of Economic Activities}

The existence of economic activities center in an area is considered important for the economic activities of the population in the area. Through the center of economic activity, the population can obtain the necessities of life, besides the population can also market the production of its business. In the study area, there are four major economic activities centers in the form of traditional market and modern market that provide daily needs for residents.

Ideally, the center of economic activities within a radius of 2,000 meters from the built-up land, this is intended to facilitate access of the population to the center of economic activities. A radius of 2,000 meters from the center of economic activities has the highest score for the built-up land sutability. Then, at a radius of 2,000 2,500 meters has a moderate score, and the area with a radius of more than 2,500 meters has a low score for the suitability of the built-up land.

Based on the result, Depok Subdistrict has the highest percentage of area that is $95 \%$ at a distance of $<2000$ meters from the center for economic activities, other than that of Cangkringan Subdistrict which has the smallest percentage of area that is $3 \%$ at the same distance. Seyegan Subdistrict is a subdistrict with the highest percentage of area for $2001-2500$ meters from the center for economic activities. Meanwhile, Cangkringan subdistrict is the subdistrict with the highest percentage of area at a distance of $>2500$ meters from the center for economic activities.

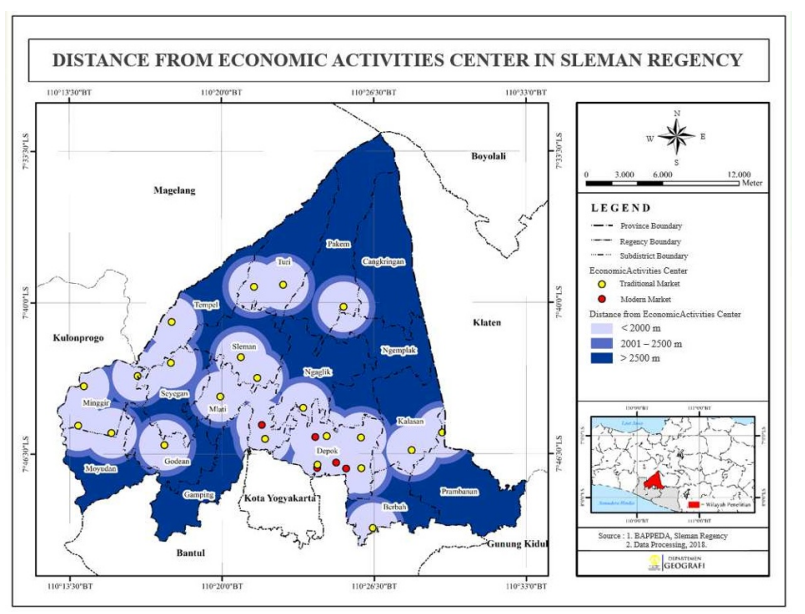

Fig. 6. Distance from Economic Activities Center Map of Sleman Regency.

Source: Data Processing, 2018

\subsection{Mount Merapi Disaster-Prone Areas}

The Mount Merapi Disaster-Prone Area (DPA) is one of the variables in determining the built-up land. DPA Zone III is certainly an area with a low suitability of the builtup land or an area that is not suitable for the built-up land. Whereas for DPA II, it is an area that is less suitable for built-up land, and for DPA I and non DPA are area that has a high suitability score for the built-up land or an area that is suitable for the built-up land.

Based on the map, we can find out there are 12 subdistricts located in the Zone I Disaster Prone Areas and the Non-Disaster Prone Areas of Mount Merapi. Then in Zone II Disaster Prone Areas there are 5 subdistricts in that zone, meanwhile in Zone III Disaster Prone Areas there are 4 subdistricts in that zone. Cangkringan has the highest percentage of area in Zone III Disaster Prone Areas, which is $47 \%$.

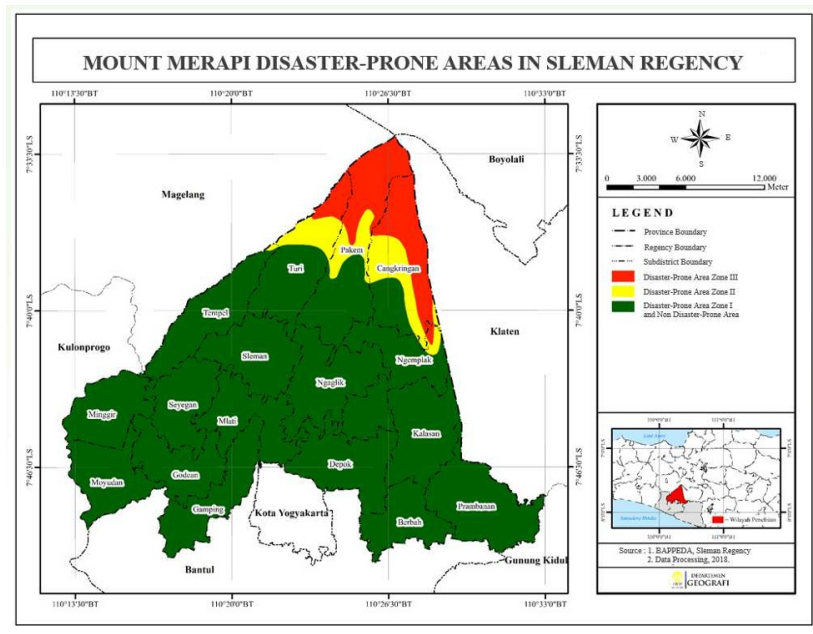

Fig. 7. Mount Merapi Disaster Prone Area Map of Sleman Regency.

Source: Data Processing, 2018 


\subsection{Built-Up Land Suitability}

The built-up land suitability is the result from the six limiting factors that combined with overlay tool and classifified with queries. Areas that suitable degree for built-up land, are assumed to be the main choice areas for establishing built-up land. Areas with less suitable are assumed to be the second preferred area in establishing the built-up land, while the last is an area of not suitable that assumed to be the most avoided areas due to unlikely land conditions but also to the river border and disaster-prone areas Zone III of Mount Merapi.

Most of the research area, Sleman Regency, is included in the area suitable for built-up land with 52,883 hectares, meanwhile the area that less suitable for builtup land only $4.581 \mathrm{Ha}$ which is focused in the north and southeast of Sleman Regency. Then the area that not suitable for built-up land is located in the northern part of Sleman Regency wit h149 Ha.

Based on Table 9, Depok becomes the only subdistrict whose entire area is included in the suitable area for built-up land with 3,074 Ha. Pakem subdistrict of 1.918 Ha entered into the less suitable class for the built-up land, followed by Cangkringan subdistrict with an area of $1460 \mathrm{Ha}$. Subdistricts that have the largest area in the class is not suitable is Pakem District, with an area of $133 \mathrm{Ha}$.

Table 9. Built-Up Land Suitability in Subdistricts of Sleman Regency

\begin{tabular}{|c|c|c|c|}
\hline \multirow{2}{*}{ Subdistrict } & \multicolumn{3}{|c|}{ Built-Up Land Suitability } \\
\cline { 2 - 4 } & Suitable & Less Suitable & $\begin{array}{c}\text { Not } \\
\text { Suitable }\end{array}$ \\
\hline Berbah & 2.315 & 6,8 & - \\
\hline Cangkringan & 3.074 & $1.460,2$ & 11,8 \\
\hline Depok & 3.474 & - & - \\
\hline Gamping & 2.917 & 5,7 & - \\
\hline Godean & 2.670 & 3,3 & - \\
\hline Kalasan & 3.471 & 0,8 & - \\
\hline Minggir & 2.705 & 2,1 & - \\
\hline Mlati & 2.887 & 0,2 & - \\
\hline Moyudan & 2.697 & 46,8 & - \\
\hline Ngaglik & 3.733 & 0,8 & - \\
\hline Ngemplak & 3.678 & 65,2 & - \\
\hline Pakem & 3.272 & $1.917,6$ & 133,1 \\
\hline Prambanan & 3.650 & 447,3 & - \\
\hline Seyegan & 2.661 & 4,0 & - \\
\hline Sleman & 3.115 & 0,5 & - \\
\hline Tempel & 3.190 & 26,1 & - \\
\hline Turi & 3.374 & 593,2 & 4,2 \\
\hline Total & 52883 & $4.580,5$ & 149,1 \\
\hline
\end{tabular}

Source: Data Processing, 2018

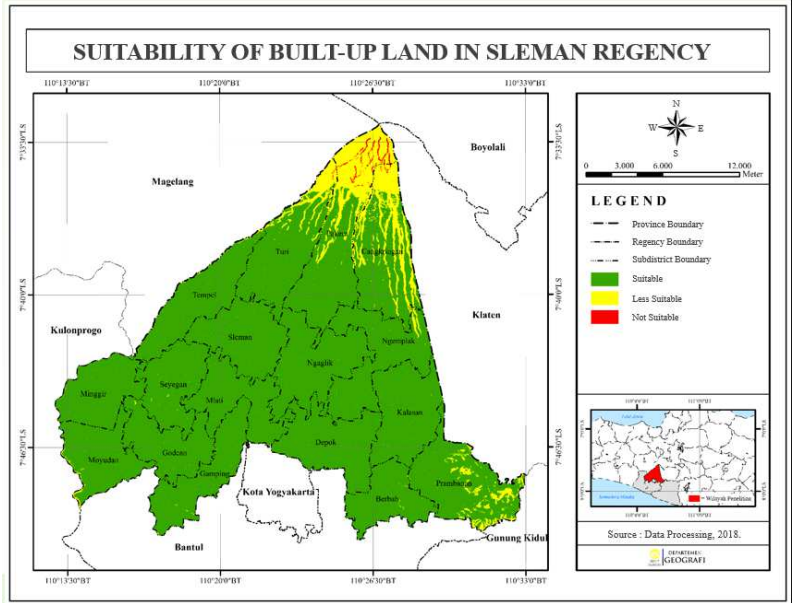

Fig. 8. Built-Up Land Suitability in Sleman Regency. Source: Data Processing, 2018

\section{Conclusions}

Population growth occurring in the research area has affected the availability of land for built-up land. The occurrence of population increase causes the need for land is increasing as well, thus, increasing the built-up land. Most of suitability area is located in the south of Sleman Regency, meanwhile most of not suitable area is located on the north that have steep and hilly terrain. The suitability area was based on variables which considering physical data and accessibility data. The number of suitable area reach about 52.883 ha, meanwhile the less suitable area about 4.581 ha, and notsuitable area reach about 149 ha. Monitoring built-up land suitability, and land use changes in the research area will be a good step to develop low carbon society.

\section{Acknowledgement}

Gratitude is addressed to Hibah PITTA 2017 from Universitas Indonesia with contract number 2314/UN2.R3.1/HKP.05.00/2018.

\section{References}

1. Baskoro, Haryo. Analisis Perubahan Penggunaan Lahan Terhadap Perubahan Kedalaman Muka Air Tanah disebagian Kabupaten Sleman (2017).

2. Arini, Nur. Identifikasi Kebutuhan dan Lokasi Fasilitas Penunjang Permukiman di Kecamatan Banyumanik Kota Semarang (2009).

3. ESRI. ArcGIS Spatial Analyst: Advanced GIS Spatial Analysis Using Raster and Vector Data (2001).

4. Poeradiredja, A. Model Dinamika Spasial Hubungan antara Pertumbuhan Penduduk dengan Ketersediaan Lahan di Kabupaten Cianjur Bagian Utara Provinsi Jawa Barat (2017)

5. Arselan, A. Variasi Penggunaan Tanah Pada Berbagai Jenis Bentukan Asal di Kabupaten Mandailing Natal (2009). 